\title{
Effects of water saving technology application on growth, development, and yield of cotton in Uzbekistan
}

\author{
Sabirjan Isaev ${ }^{1, *}$, Sayidjakhon Khasanov ${ }^{1,2,3,4}$, Yusufbay Ashirov², Azim Gafurov², and Tokhtakhon \\ Karabaeva ${ }^{2}$ \\ ${ }^{1}$ Tashkent Institute of Irrigation and Agricultural Mechanization Engineers, Kari Niyazi str.,39, \\ 100000, Tashkent, Uzbekistan \\ ${ }^{2}$ Tashkent State Agrarian University, University str., 2, 100140, Tashkent, Uzbekistan \\ ${ }^{3}$ Institute of Geographical Sciences and Natural Resources Research, Chinese Academy of Sciences, \\ Datun Road, 11A, Beijing, China, 100101 \\ ${ }^{4}$ University of Chinese Academy of Sciences, Yuquan Road, 19A, Beijing, China, 100049
}

\begin{abstract}
The highest yield of the promising cotton variety Pakhtakor-1 was achieved by irrigating the cotton with placing black plastic film. Accordingly, the average yield for 3 years was $37.2 \mathrm{q} / \mathrm{ha}$, which was more by $7.9 \mathrm{q} / \mathrm{ha}$ than the control variant, whereas it was higher by $2.7 \mathrm{q} / \mathrm{ha}$ than Bayaut-2 variety of cotton, in which the same irrigation method was applied. It was found that in Pakhtakor-1 variety, fiber yield was 38.1$39.9 \%$, followed by fiber length $33.5-34.0 \mathrm{~mm}$ and weight of 1000 seeds was 115-120.1 grams. Cotton fiber yield, fiber length and weight of 1000 seeds in Pakhtakor-1 for the three years were higher by $0.2-1.0 \%, 0.1-0.7$ $\mathrm{mm}$ and 0.4-1.6 mm, correspondingly, than the standard An-Bayaut-2. The highest economic efficiency of cultivating standard An-Bayaut-2 and promising cotton varieties Pakhtakor-1 through various irrigation technologies was achieved in the form of irrigated with black plastic film, accounted for net profit of 1943902 sums/ha (45\% profitability rate) and 870,583 sums of additional income $(17.2 \%$ the profitability rate) than the control.
\end{abstract}

\section{Introduction}

Today, one of the ten global challenges of the 21 st century is the acute shortage of water resources. In the last 60 years, drinking water consumption on our planet has increased by 8 folds. By the middle of the century, many countries will be forced to import water. Water is a very limited resource, and the acquisition of its resources is already one of the causes of tensions and conflicts around the world [1-3]. According to the International Commission on Irrigation and Drainage, there are 299.488 million hectares of irrigated land in the

\footnotetext{
${ }^{*}$ Corresponding author: sabirjan.isaev@,mail.ru
} 
world. The world agriculture uses 2.8 thousand $\mathrm{km}^{3}$ of fresh water per year, accounts for $70 \%$ of the world's freshwater consumption, and it is 7 times more than the water used by world industry. Almost all of this water is used to irrigate crops, and globally, $40 \%$ of food and $60 \%$ of cereals crops are produced in irrigated land.

Extensive irrigation and reclamation measures are being taken in Uzbekistan to improve the reclamation of irrigated lands, increase soil fertility, efficient use of available water resources in the face of water shortages, and the formation of additional water sources [6-7, 12]. As a result of these measures, 13.2 thousand hectares have been irrigated with drip irrigation, 18 thousand hectares have been irrigated with placing black plastic film, and 16.8 thousand hectares have been irrigated with portable flexible pipes instead of ditches [10-14]. The reclamation of 1.2 million hectares has been improved and the area of strongly and moderately saline lands decreased by 149.4 thousand hectares, the area of groundwater near the ground decreased by 302.9 thousand hectares. The water supply of $1 \mathrm{mln} 300,000$ hectares of land has been improved, the yield of cotton in the reclaimed lands has increased by 3-4 q/ha and the yield of wheat by 4-5 q/ha. In this regard, scientific researches on water scarcity, water-saving irrigation water and improving the reclamation of lands by further improving intensive methods, the water-saving technology of cotton in the country are of great importance [1-3, 12]. The impact of irrigation methods, procedures, techniques and technologies of irrigation of agricultural crops on the water-physical properties of the soil, the order of nutrients, the growth, development, yield and quality of plants was studied by S.N.Rijov, V.E.Eremenko, A.F. Makarov, M.P. Mednis, A.E. Nerozin, M. Azizov, M.F. Peresokov, P.V.Starov, R.Axmedov, S.A.Gildiev, S.Nabixo'jaev, F.M.Sattarov, Q.M. Mirzajonov, N.F.Bespalov, G.A. Bezborodov, B.F. Kambarov, R.K. Ikramov, M.X. Khamidov, A.E.Avliyaqulov, B. Mambetnazarov, A.S.Shamsiev, S.X.Isaev, T.Rajabov, M.Mahmudov, J.Shadmanov, M. Hasanov, Sh.Qodirov, Yu. Esanbekov, and international scientists, such as D.Balla, S. Maasen, J. Andersson, B. Wedding, K.Toderski, KMKeinzler, A.S. Qureshi, M. Qadir [5-9, 12-14].

However, it was found that no research has been conducted on the growth and yield of cotton varieties An-Bayaut-2 and Pakhtakor-1 in Jizzakh region in the conditions of meadow-gray, lightly sandy, weakly saline soils, groundwater level at a depth of one meter. Therefore, this research was intended 1) to determine the impact of different irrigation technologies on the conditions of irrigation of standard An-Bayaut-2 and promising Pakhtakor-1 varieties of cotton in the conditions of meadow gray soils, 2) to determine the impact of water-saving irrigation technologies on cotton varieties in the amount of nutrients in the soil, to study of the impact of water-saving irrigation technologies on seedling thickness, growth and development of cotton varieties, 3) to determine the impact of watersaving irrigation technologies on the yield of cotton varieties and technological quality of cotton fiber, and 4) to identify the cost-effectiveness of improved water-saving irrigation technologies that provide optimal irrigation regimes for cotton varieties.

\section{Materials and methods}

In this research, the field experiments were conducted in 2014-2016 at the Jizzakh experimental station of Research Institute of Cotton Breeding, Seed Production and Cultivation Agrotechnology (RICBSPCA). Meadow-gray, light sandy soils in mechanical composition and medium-fiber standard cotton varieties An-Bayaut-2 and promising Pakhtakor-1 were taken for the research experiment. 
In the field and laboratory experiments, "Methods of conducting experiments with cottonseed" [3-4], "Methods of agrochemical analysis of soil and plants" [5], "Analysis of agrophysical properties of soil" [6], "Methods of conducting field experiments" [7], manuals, which were adopted at the Scientific Research Institute of Agrotechnology, were used. For performing the agrochemical analysis, the experimental field as the form of envelopes were cut soil sections (incisions) up to 1-1.5 m, soil samples were taken from genetic layers and the amount of humus in the soil (I.V.Tyurin), total nitrogen and phosphorus A.F.Gritsenko, the change of I.M. Maltseva, the amount of nitrate nitrogen was determined by the method of Grandvald-Lyaju, the amount of mobile phosphorus was determined by the method of B.P. Machigin, the volume mass of the soil (S.N.Rijov) was determined by the cylindrical method, the structure was determined by the method of I.V. Savvinov. The experiment consisted of 8 variants with each three iterations. The variants were located in one tier, the area of one plot was $480 \mathrm{~m}^{2}$.

\section{Results and discussion}

According to the analysis of soil samples at experimental station of RICBSPCA in Jizzakh in Uzbekistan, meadow gray, mechanical composition of light sand, groundwater level was at a depth of 2.0-2.5 m, the amount of humus in the drive $(0-30 \mathrm{~cm})$ layer was $1.101 \%$, total nitrogen was $0.080 \%$ and phosphorus was $0.135 \%$, whereas humus was 0.483 , total nitrogen was 0.083 and phosphorus was $0.103 \%$ in the $30-50 \mathrm{~cm}$ layer. The amount of nitrate nitrogen in the driving and sub-driving layers was $22.2-11.5 \mathrm{mg}$ per $1 \mathrm{~kg}$ of soil, mobile phosphorus was 32.0-20.5 and exchangeable potassium was $145-103 \mathrm{mg} / \mathrm{kg}$. Hence, it was found that the driving layer of the experimental field was moderately supplied with mobile phosphorus, and low in nitrate nitrogen and exchangeable potassium (Table 1).

Table 1. Experiment system

\begin{tabular}{|c|c|c|c|c|}
\hline \multirow{2}{*}{ 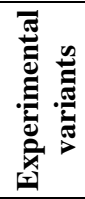 } & \multirow[b]{2}{*}{$\begin{array}{l}\text { Surface irrigation technologies } \\
\text { for cotton }\end{array}$} & \multirow[b]{2}{*}{$\begin{array}{c}\text { Cotton } \\
\text { varieties }\end{array}$} & \multicolumn{2}{|c|}{ Measured layers of soil, $\mathrm{cm}$} \\
\hline & & & $\begin{array}{c}\text { Determine } \\
\text { timing of } \\
\text { irrigation }\end{array}$ & $\begin{array}{l}\text { Determine timing of } \\
\text { irrigation standards }\end{array}$ \\
\hline 1 & $\begin{array}{l}\text { Approved irrigation in production } \\
\text { (control) }\end{array}$ & \multirow{4}{*}{$\begin{array}{c}\text { An-Bayaut } \\
2\end{array}$} & $\begin{array}{c}\text { Actual } \\
\text { measurements }\end{array}$ & Actual measurements \\
\hline 2 & Furrow irrigation & & $70-100-70$ & \multirow{3}{*}{$\begin{array}{c}\text { On the moisture } \\
\text { deficit of } 50-100-70 \\
\mathrm{~cm}\end{array}$} \\
\hline 3 & $\begin{array}{l}\text { Furrow irrigation with placing } \\
\text { black plastic film }\end{array}$ & & $50-70-50$ & \\
\hline 4 & Furrow irrigation by opposite side & & $70-100-70$ & \\
\hline 5 & $\begin{array}{l}\text { Approved irrigation in production } \\
\text { (control) }\end{array}$ & \multirow{4}{*}{$\begin{array}{c}\text { Pakhtakor } \\
1\end{array}$} & $\begin{array}{c}\text { Actual } \\
\text { measurements }\end{array}$ & Actual measurements \\
\hline 6 & Furrow irrigation & & $70-100-70$ & \multirow{3}{*}{$\begin{array}{c}\text { On the moisture } \\
\text { deficit of } 50-100-70 \\
\mathrm{~cm}\end{array}$} \\
\hline 7 & $\begin{array}{l}\text { Furrow irrigation with placing } \\
\text { black plastic film }\end{array}$ & & $50-70-50$ & \\
\hline 8 & Furrow irrigation by opposite side & & $70-100-70$ & \\
\hline
\end{tabular}

Note: $70-70-60 \%$ relative to limited field moisture capacity (LFMC) 
The advanced water-saving technology of furrow irrigation was used for three years towards irrigating standard An-Bayaut-2 and promising Pakhtakor-1 varieties of cotton. In comparison with LFMC, it was found that there were effective waterway technology measures leading to an increase in soil moisture, porous irrigation procedure, seasonal water standard, nutrients in the soil, planting thickness, porous growth, development, yield, quality indicators of cotton fiber when watered at 70-70-60 percent. The limited field moisture capacity of the experimental field soil was $19.0-19.6 \%$ relative to the absolute dry mass of the soil in the $0-50 \mathrm{~cm}$ layer, followed by $19.5-20.2 \%$ in the $0-70 \mathrm{~cm}$ layer and $20.6-20.9 \%$ in the $0-100 \mathrm{~cm}$ layer of soil. In the experiment, the porosity of the soil was $50.0 \%$ in the spring driving layer $(0-30 \mathrm{~cm})$ and $49.7 \%$ in the $30-50 \mathrm{~cm}$ driving layer, while at the end of the growing season the soil porosity was $0-30$ and $0-50 \mathrm{~cm} .48 .6-48.7$ and $47.8-48.1 \%$ in the 2 and 5 variants irrigated intermittently, $49.3-49.5 \%$ and $48.6 \%$ in the 3 and 7 variants irrigated with black film. 49.0\%, 48.9-49.0 and 48.2-48.0\%, respectively, in the 4 and 8 variants irrigated by the opposite side of the cotton field. Furthermore, in the 0 70 and $0-100 \mathrm{~cm}$ layers of the soil, the porosity of the soil was $47.4-47.9$ and $46.7-47.1 \%$ (2 and 5 variants), 48.5-48.6 and 47.7. - -48.3\% (3 and 7 variants), 47.6-47.5 and 47.0-47.2\% (4 and 8 variants), respectively, and compared to the initial case, it was decreased by $0.7-1.9 \%$ and $0.6-2.2 \%$, correspondingly.

In the experiment, a relatively high index of soil porosity $(0.7-1.2 \%)$ was observed in the variants 3 and 7, in which furrow irrigation with placing black plastic film was applied. Clearly, in these variants, the field was no longer treated with the technique and the irrigation standards were low when furrow irrigation with placing black plastic film was employed. The water permeability of the soil depends on the granulometric composition and chemical properties of the soil, its structural state, density, porosity, moisture and duration of wetting. Water permeability is always lower in soils with heavy mechanical granulometric content than in soils with light mechanical content. Water permeability varies depending on the volume of water passing through the soil cross-sectional surface per unit time. The water permeability of the soil was decreased in autumn as a result of irrigation in the growth period of 2015 years and the passage of their norms and techniques working between them led to the condensation of the soil. The water permeability of the soil was $1207-1260 \mathrm{~m}^{3} /$ ha in furrow irrigation used variants 2 and 6 , followed by 1249 $1405 \mathrm{~m}^{3} /$ ha in variants 3 and 7 , in which furrow irrigation with placing black plastic film was applied, and it was $1284-1290 \mathrm{~m}^{3} / \mathrm{ha}$. in furrow irrigation by opposite side used variants 4 and 8 . The rate of water absorption into the soil was $0.78-0.87 \mathrm{~mm} /$ minute in the first hour and $0.10-0.12 \mathrm{~mm} /$ minute by the sixth hour. In variant 3 and 7 , it was $0.85-0.96$ and $0.10-0.12 \mathrm{~mm} /$ minute, respectively, whereas in variants 4 and 8 , it was $0.82-0.85$ and $0.12-0.14 \mathrm{~mm} / \mathrm{minute}$. At the beginning of the growing season, the moisture reserve in the $0-250 \mathrm{~cm}$ layer of soil was $29.8 \%$, and at the ending of the season, especially in furrow irrigation used variants, it was $26.7 \%$ in the $0-250$ soil layer. In furrow irrigation with placing black plastic film and furrow irrigation by opposite side applied variants, the moisture reserve was $29.2-25.7 \%$ and $29.8-26.5 \%$, respectively. When irrigating cotton during the growing season, the established pre-irrigation soil moisture regime was fully followed, and the error did not exceed 0.6-2.0 percent.

The research results showed that when the soil moisture before pre-irrigation relative to the LFMC was 70-70-60\%, irrigation was carried out twice in the 0-2-0 system during the period of application in the 1-8 variants. Accordingly, soil moisture before the preirrigation was $68.2-72.0 \%$. In furrow irrigation with placing black plastic film used variants 3 and 7, the cotton was irrigated three times during the growing season in a 1-2-0 system, 
and the pre-irrigation soil moisture was found to be on average $70.2-72.0 \%$. In order to maintain the soil moisture before irrigation in the amount of $70-70-60 \%$ relative to the limited field moisture capacity, the cotton in 0-2-0 system was irrigated twice during the application period in 1,2-2,5,6 and 8 variants. Each iteration of irrigation consumed 890$1250 \mathrm{~m}^{3} /$ ha of water, which resulted in a high level of moisture in the active layer of the soil, and the norm of seasonal irrigation was $1795-2445 \mathrm{~m}^{3} /$ ha. In variants 3 and 7 , in which furrow irrigation with placing black plastic film was used, cotton was required to be irrigated 3 times in a 1-2-0 system during the growing season to maintain soil moisture around $70-70-60 \%$ relative the limited field moisture capacity. At the same time, 400-630 $\mathrm{m}^{3} /$ ha of water was used for each irrigation, and 1590-1650 $\mathrm{m}^{3} /$ ha during the season. After irrigation, it was found that the groundwater level increased to $11-14 \mathrm{~cm}$ in the variants irrigated using methods, such as furrow irrigation and furrow irrigation by opposite the furrows. However, in the furrow irrigation with placing black plastic film used variants, almost no changes were observed $(0-2 \mathrm{~cm})$. In the experiment, high irrigation rates $(890$ $1020 \mathrm{~m}^{3} / \mathrm{ha}$ ) were observed in the variants $2,4,6$ and 8 (the methods of furrow and furrow irrigation by opposite side were used), whereas it was $400-630 \mathrm{~m}^{3} /$ ha in variants 3 and 7 (furrow irrigation with placing black plastic film was used). It was found that the maximum increase in the groundwater level due to irrigation was $17-20 \mathrm{~cm}$ in the control variant, which irrigated with large irrigation norms as $1100-1250 \mathrm{~m}^{3} / \mathrm{ha}$.

Compared to the initial amount of humus in the soil in 2015 (in the layer of $0-30 \mathrm{~cm}$ ), in control variants 1 and 5, humus was $0.058-0.158 \%$, followed by nitrate nitrogen with 8.5 $8.0 \mathrm{mg} / \mathrm{kg}$, phosphorus with $16.3-14.3 \mathrm{mg} / \mathrm{kg}$, potassium with $90-100 \mathrm{mg} / \mathrm{kg}$. In furrow irrigation used variants 2 and 6 , humus was $0.040-0.036 \%$, nitrate nitrogen was 7.7-7.3 $\mathrm{mg} / \mathrm{kg}$, mobile form of phosphorus was $14.6-14.0$, potassium was 73-60 mg/kg. In variants 3 and 7 , in which the furrow irrigation with placing black plastic film was used, humus was $0.019-0.022 \%$, nitrate nitrogen was $9.0-8.0 \mathrm{mg} / \mathrm{kg}$, phosphorus was $15.9-16.2 \mathrm{mg} / \mathrm{kg}$, potassium was $89-83 \mathrm{mg} / \mathrm{kg}$. Last but not least, in the variants 4 and 8 , in which furrow irrigation by opposite side was applied, humus was $0.033-0.039 \%$, nitrate nitrogen was 6.9-6.3 mg/ha, phosphorus was13.1-12.1 mg/ ha, and potassium $63-53 \mathrm{mg} / \mathrm{ha}$. In the furrow irrigation with placing black plastic film used variants 3 and 7 , the humus content in the soil was improved by $0.014-0.021 \%$. Due to the creation of favorable conditions, cotton varieties were found to absorb more nitrate nitrogen by $0.7-2.3 \mathrm{mg} / \mathrm{kg}$., mobile phosphorus by $1.3-2.8 \mathrm{mg} / \mathrm{kg}$. and exchangeable potassium by $16-26 \mathrm{mg} / \mathrm{kg}$.

Proper selection of seedling thickness and taking into account the biological properties of cotton can ensure a high and quality cotton crop. At the optimal seedling thickness, moisture in the soil is used well and fully, moisture evaporates from the soil surface and waste is reduced. Obviously, after the cotton seedlings were fully germinated, they were singled out when 2-3 petals appeared on them. The actual seedling thickness picked in 2015 was the highest seedling thickness in the standard An-Bayaut- 2 cotton variety; it was 88.2 in the furrow irrigation by opposite side applied variant, it was 87.1 in the variant, in which furrow irrigation with placing black plastic film, and it was 86.3 in the furrow irrigation used variant. In the lowest seedling thickness was in the control variant, accounted for 82.9 thousand piece/ha, and in the promising cotton variety Pakhtakor-1, it was $81.4,85.7,88$ and 86.1 thousand piece/ha in the variants $5-8$.

The experiment had different effects on the growth, development, and yield of cotton varieties when water-efficient irrigation technologies were applied. In the furrow irrigation with placing black plastic film used variants 3 and 7 , the number of plots was 11.0-12.7. The highest number of open pods was also in the variants 3 and $7(3,8-6,4)$. In 
order to determine the weight of one bale of cotton, 100 samples were collected before each harvest from all options and returns in the experimental field. An-Bayaut- 2 cotton varieties planted in the variants 1-4, and the average weight of cotton in one bale was 4.27-4.40 grams. Whereas, the promising Pakhtakor- 1 cotton varieties planted in the variants 5-8, the weight was $4.22-4.34$ grams, and the weight of cotton in one stalk was $0.5-0.6$ grams higher.

In order to determine the effect of irrigation technologies on the yield of cotton varieties in the experiments, 2 hand-pickings were carried out on all returns from each variant. In the experiment, the highest yield (on average in 3 year) was 37,2 q/ha in the variant 7, which was reached through leaving 84,0 thousand bush seedlings per hectare, feeding in the norm of N-200, R-140 and K-100 kg/ha with mineral fertilizers, and considering the soil moisture before irrigation as in the order of $70-70-60 \%$ relative to the LFMC. In the experiments, the additional yield was $0.7-3.2 \mathrm{q} / \mathrm{ha}$ at the expense of the variety (variants 58.). At the expense of irrigation technologies in the standard An-Bayaut- 2 cotton variety (variants 1-4) it was $0.5-6.3 \mathrm{q} / \mathrm{ha}$ whereas it was $0.7-7.9 \mathrm{q} / \mathrm{ha}$ in the variants $5-8$ of the promising Pakhtakor-1 cotton variety (Table 2).

Table 2. Influence of different irrigation method on the cotton productivity.

\begin{tabular}{|c|c|c|c|c|c|c|c|c|}
\hline \multirow[b]{2}{*}{ 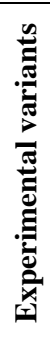 } & \multirow[b]{2}{*}{ } & \multirow[b]{2}{*}{ 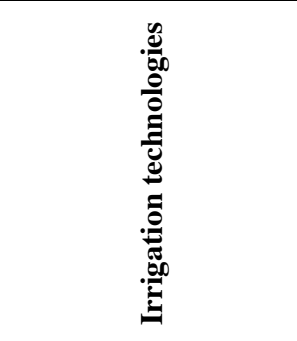 } & \multicolumn{3}{|c|}{ Years } & \multirow[b]{2}{*}{ 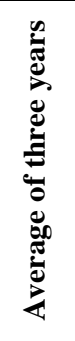 } & \multicolumn{2}{|c|}{ Difference, \pm} \\
\hline & & & 2014 & 2015 & 2016 & & 象 & 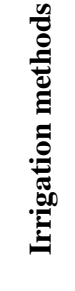 \\
\hline 1 & \multirow{4}{*}{$\begin{array}{c}\text { An-Bayaut } \\
2\end{array}$} & Control & 26.8 & 28.4 & 29.4 & 28.2 & - & - \\
\hline 2 & & Furrow irrigation & 27.1 & 28.8 & 30.3 & 28.7 & - & +0.5 \\
\hline 3 & & $\begin{array}{c}\text { Furrow irrigation with } \\
\text { placing black plastic } \\
\text { film }\end{array}$ & 32.5 & 34.1 & 37.1 & 34.5 & - & +6.3 \\
\hline 4 & & $\begin{array}{c}\text { Furrow irrigation by } \\
\text { opposite side }\end{array}$ & 26.4 & 30.6 & 34.6 & 30.5 & - & +2.3 \\
\hline 5 & \multirow{4}{*}{ Pakhtakor 1} & Control & 28.3 & 29.1 & 30.5 & 29.3 & +1.1 & - \\
\hline 6 & & Furrow irrigation & 29.6 & 30.8 & 32.7 & 31.0 & +2.3 & +0.7 \\
\hline 7 & & $\begin{array}{c}\text { Furrow irrigation with } \\
\text { placing black plastic } \\
\text { film }\end{array}$ & 34.7 & 37.3 & 39.8 & 37.2 & +2.7 & +7.9 \\
\hline 8 & & $\begin{array}{c}\text { Furrow irrigation by } \\
\text { opposite side }\end{array}$ & 29.0 & 32.6 & 35.1 & 32.2 & +1.7 & +2.9 \\
\hline
\end{tabular}

The influence of irrigation methods on the technological quality of cotton fiber cotton varieties was significant. The results of extensive research showed that obtaining high and high-quality cotton yields of cotton under optimal irrigation regimes and irrigation methods, fiber quality indicators of cotton was improved. In the experiments, the highest technological quality of cotton fiber was observed in variants 3 and 7, in which Furrow irrigation with placing black plastic film was used. Accordingly, the fiber yield was 38.1$39.9 \%$, fiber length was 33.5-34.0 mm, weight of 1000 seeds was 115.1-120.1 grams. 
It was found that in 2016, the fiber yield was higher by $0.2-1.0 \%$, followed by $0.1-0.7$ $\mathrm{mm}$ fiber length, and weight of 1000 seeds was higher by $0.4-1.6$ grams in the 5-8 variants of Pakhatkor than the 1-4 variants of An-Bayaut-2 variety. The minimum water consumption for growing 1 quintal crop/ha from the cotton varieties, Pakhtakor-1 and AnBayaut-2 was achieved through applying the methods called furrow irrigation with placing black plastic film. This figure was $41.3-46.0 \mathrm{~m}^{3} / \mathrm{q}$ in the promising cotton variety Pakhtakor-1, which was less by $32.5-38.1 \mathrm{~m}^{3} / \mathrm{q}$ than in the control variant. Furthermore, it was also less by $3.2-3.5 \mathrm{~m}^{3} / \mathrm{q}$ than in the An-Bayaut- 2 variety in which the same irrigation technology was used.

In the control variant of the study (2014), the specific water consumption of the standard An-Bayaut-2 cotton variety was $91.2 \mathrm{~m}^{3}$, the total water consumption was 181.6 $\mathrm{m}^{3}$. However, in the promising Pakhtakor-1 variety, these figures were 84.1 and $169.6 \mathrm{~m}^{3}$, correspondingly.

The data obtained on the economic efficiency of agro-measures used in the experiment in cotton were given. All agro-technical measures, including irrigation and harvesting costs, were taken into account in determining the economic efficiency of the cotton varieties, the An-Bayaut-2 and Pakhatakor-1 in relation to the irrigation technologies. Conditional net profit for irrigation (control option) adopted in the production of standard cotton varieties An-Bayaut-2 and promising "Pakhtakor-1 was 888,222-1,073,319 sums/ha for three years, the profitability rate was $23.0-27.8 \%$. The best results were observed in both cotton varieties in the furrow irrigation with placing black plastic film applied variants: conditional net profit was 1,489,573-1,943,902 sums/ha, and yield was 34.5 and $45.0 \%$, respectively. Compared to the control variants, the additional income, 601,351-870,583 sums were earned, and profitability was increased by 11.5 and $17.2 \%$ in the both varieties, correspondingly. As a result of the different irrigation technologies applied to the Pakhatkor-1 variety, high-quality crop was obtained, and high economic efficiency was achieved due to the reduction of production costs.

\section{Conclusion}

The soil of the experimental field was meadow-burrow, light coarse soil with a mechanical composition, low in humus and nitrogen from nutrients, moderate in phosphorus and high in potassium. In the experiment, the porosity of the soil was $50.0 \%$ in the spring driving layer $(0-30 \mathrm{~cm})$ and $49.7 \%$ in the $30-50 \mathrm{~cm}$ driving layer, while at the end of the growing season the soil porosity was $0-30$ and $0-50 \mathrm{~cm}$. 48.6-48.7 and 47.8$48.1 \%$ in the 2 and 5 variants irrigated intermittently, $49.3-49.5 \%$ and $48.6 \%$ in the 3 and 7 variants irrigated with black film. 49.0\%, 48.9-49.0 and 48.2-48.0\%, respectively, in the 4 and 8 variants irrigated by the opposite side of the cotton field. Furthermore, in the $0-70$ and $0-100 \mathrm{~cm}$ layers of the soil, the porosity of the soil was $47.4-47.9$ and $46.7-47.1 \%$ (2 and 5 variants), 48.5-48.6 and 47.7. -48.3\% (3 and 7 variants), 47.6-47.5 and 47.0-47.2\% (4 and 8 variants), respectively, and compared to the initial case, it was decreased by $0.7-1.9 \%$ and $0.6-2.2 \%$, correspondingly.

The water permeability of the soil was $1207-1260 \mathrm{~m}^{3} / \mathrm{ha}$ in furrow irrigation used variants 2 and 6 , followed by $1249-1405 \mathrm{~m}^{3} /$ ha in variants 3 and 7 , in which furrow irrigation with placing black plastic film was applied, and it was $1284-1290 \mathrm{~m}^{3} / \mathrm{ha}$. in furrow irrigation by opposite side used variants 4 and 8 . The rate of water absorption into the soil was $0.78-0.87 \mathrm{~mm} /$ minute in the first hour and $0.10-0.12 \mathrm{~mm} /$ minute by the sixth 
hour. The best results in the observations made on August 1, 2015 were in furrow irrigation with placing black plastic film used variants 3 and 7 . Accordingly, the height of the cotton stalk was $102.3-104.1 \mathrm{~cm}$, the number of branches was 13.4-13.9, the number of nodules was 2.9-3.2 and the number of pods was 8.1-8.4. The best results in the observations made on September 1 were observed in the order of $70-70-60 \%$ of the irrigations in relation to the LFMC. The best results were observed in both cotton varieties in the furrow irrigation with placing black plastic film applied variants: conditional net profit was 1,489,573-1,943,902 sums/ha, and yield was 34.5 and $45.0 \%$, respectively.

We are grateful to the head of the Jizzakh Experimental Station of the Research Institute of Cotton Breeding, Seed Production and Agrotechnology for the implementation of this research under the priority direction of the Republican Development of Science and Technology V. "Agriculture, Biotechnology, Ecology and Environmental Protection".

\section{References}

1. J. Wang, G. Du, J. Tian, Y. Zhang, C. Jiang, W. Zhang, Agricultural Water Management, 234 (2020)

2. Sh. Kenjabaev G.F. Hans, I., Begmatov, S. Isaev, B. Matyakubov, Journal of Critical Reviews 7, 6 (2020)

3. S. Isaev, SH. Mardiev, Z. Qodirov, Journal of Critical Reviews 7, 6 (2020)

4. R. Kulmatov, A. Taylakov, S. Khasanov, Environmental Science and Pollution Research, 1-11 (2021)

5. S. Isaev, A. Jumanov, M. Avlakulov, A. Tabaev, E. Malikov, Journal of Critical Reviews 7, 9 (2020)

6. S. Isaev, B. A. Haydarov, S. Sh. Zakirova, Journal of Critical Reviews 7, 12 (2020)

7. A. Jumanov, S. Khasanov, A. Tabayev, G. Goziev, U. Uzbekov, E. Malikov, IOP Publishing 614(1), 012150 (2020)

8. S. Isaev, Y. R. Ashirov, U. T. Sultanov, Journal of Critical Reviews 7, 12 (2020)

9. S. Isaev, I. Begmatov, G. Goziev, S. Khasanov, IOP Publishing 883(1), 012080 (2020)

10.S. K. Isaev, R. U. Rakhmonov, S. S. Tadjiev, G. I. Goziev, S. Z. Khasanov, IOP Publishing 614(1), 012147 (2020)

11.A.G. Bezborodov, Collection of materials of the international scientifically-practical conference, 33-39 (2016)

12. K. Allanov, A. Shamsiev, N. Durdiev, M. Avliyakulov, A. Karimov, B. Khaitov, Journal of Plant Nutrition 43, 17 (2020)

13. M. Khamidov, K. Khamraev, S. Azizov, G. Akhmedjanova, Journal of Critical Reviews 7, 11 (2020)

14. R. A. Kulmatov, S. A. Adilov, S. Khasanov, IOP Publishing 614(1), 012149 (2020) 